\title{
A Study on Risk and Return Management in Automobile Industry
}

\author{
Adarsh N. ${ }^{1}$, G Narayana Swamy ${ }^{2}$ and Harani B. ${ }^{3}$ \\ ${ }^{1}$ Student and ${ }^{2 \& 3}$ Assistant Professor, \\ School of Commerce, REVA University, Bengaluru, India.
}

CITATION: Adarsh, N.; Swamy, G Narayana and Harani, B. (2019), "A Study on Risk and Return Management in Automobile Industry", MERC Global's International Journal of Management, Vol. 7, Issue 4, pp. 266-275.

ARTICLE HISTORY: Submitted: April 19, 19, Revision received: May 30, 2019, Accepted: June 26,2019

ARTICLE TYPE: Research paper

\begin{abstract}
Successful investment needs a vigilant valuation of the investment's possible returns and its risk of loss. A firm's risk and expected returns directly affect its share price. In real-life situations, the risk of any sole investment would not be observed individually of other assets. New investment needs to be considered in light of their impact on the risk and return of the portfolio. In traditional financial analysis, investment management tools allow investors to assess the return and risk of individual investments and portfolios. Generally, the higher the possible return of an investment, the greater the risk. There is no assurance that you will really get a sophisticated return by accepting extra risk. So, a universal understanding of this phenomenon is not sufficient to make correct decisions connecting to investments. A more critical analysis is required to know the investment. This study helps us to understand how the companies diversify themselves in automobile industry and in different companies to maximise the returns and to minimize the risks involved in it.
\end{abstract}

KEYWORDS: Risk, Return, Investment, Portfolio management, Automobile industry.

\section{BIBLIOGRAPHY}

1. Aliu, F.; Pavelkova, D. and Dehning B. (2017), "Portfolio risk and return analysis: the case of the automotive industry in the Czech Republic", Journal of International Studies, Vol. 10, Issue 4, p. 72-83.

2. Balaji, C. H. and Kumar, G. Praveen (2016), "Title: An assessment of stock performance of selected public \& private sector banks in India", Vol. 7, Issue 30, pp. 13-19.

3. Gupta, Aloke and Sur, Debasish (2016), "Business and financial risk in Indian automobile industry: an empirical investigation", Vidyasagar University Journal of Commerce, Vol. 21, pp. 73-87.

4. Krishnan, Gopala; Muthu, M. and Akarsh, P. K. (2017), "Equity analysis of automobile industry in Indian stock market", International Journal of Advance Research \& Development, Vol. 2, Issue 5, pp. 166-171.

5. Krishnapradha, S. and Vijayakumar, M. (2015), "A study on risk and return analysis of selected stocks of India", International Journal of Scientific Research and Management, Vol. 3, Issue 4, pp. 2550-2554.

6. Sankeerthana, S. and Neeraja, K. (2018), "A Report on Equity Analysis of Automobile Sector", International Journal of Engineering Technology, Science and Research, Vol. 5, Issue 3, pp. 1560-1565.

7. Srivastha, Anubha (2014), "Comprehensive study of performance of Indian automobile industry- a stock market perspective", Socio-economic Voices, pp. 1-28.

8. Sudha, V.; Umamaheswari, R. and Venkateshwaran, P. S. (2017), "Financial risk analysis of selected automobile industries in India”, IAEME, Vol. 8, Issue 6, pp. 56-61. 